Article

\title{
Synthesis of a New ent-Cyclozonarone Angular Analog, and Comparison of Its Cytotoxicity and Apoptotic Effects with ent-Cyclozonarone
}

\section{Natalia Quiñones Sobarzo ${ }^{1}$, Iván Montenegro Venegas ${ }^{1}$, Cristian Salas Sánchez ${ }^{2}$, Luis Espinoza Catalán ${ }^{3}$, Cristóbal Carrasco Rojas ${ }^{4}$, Valentina Ulloa Valdivia ${ }^{4}$, Joan Villena García ${ }^{4, *}$ and Mauricio Cuellar Fritis ${ }^{1, *}$}

1 Facultad de Farmacia, Universidad de Valparaíso, Av. Gran Bretaña N ${ }^{\circ} 1093$, Valparaíso, Chile

2 Facultad de Química, Pontificia Universidad Católica de Chile, Vicuña Mackenna $N^{\circ} 4860$, Santiago, Chile

3 Departamento de Química, Universidad Técnica Federico Santa María, Av. España N 1680, Valparaíso, Chile

4 Centro de Investigaciones Biomédicas, Escuela de Medicina, Universidad de Valparaíso, Av. Hontaneda $\mathrm{N}^{\circ}$ 2664, Valparaíso, Chile

* Authors to whom correspondence should be addressed; E-Mails: juan.villena@uv.cl (J.V.G.); mauricio.cuellar@uv.cl (M.C.F.).

Received: 9 April 2013; in revised form: 4 May 2013 / Accepted: 6 May 2013 /

Published: 13 May 2013

Abstract: The synthesis of a newangular analog 11 of cyclozonarone was achieved via Diels-Alder reaction between a sesquiterpene-1,3-diene and 1,4-benzoquinone. The cytotoxic activity of ent-cyclozonarone $[(+)-10]$ and the angular (-)-cyclozonarone analog $\mathbf{1 1}$ has been determined in three human cancer cell lines and in normal fibroblasts using the sulforhodamine B assay. The analyzed isomers induce cell death in different cancer cell lines by eliciting nuclear condensation and fragmentation, decreasing mitochondrial membrane permeability and increasing caspase- 3 activity, all traits indicating apoptosis, with the effects of (+)-10 being stronger than those of $\mathbf{1 1}$ in all cases.

Keywords: sesquiterpenequinone; ent-cyclozonarone; cancer cells; cytotoxicity; apoptosis; caspase 3 ; mitochondrial membrane permeability 


\section{Introduction}

Sesquiterpene-substituted quinones and related molecules constitute an important class of bioactive marine natural products [1], which includes the cytotoxic, antiviral and antifungal sponge metabolites puupehenone (1) and puupehedione (2), isolated from sponges, mainly of the orders Verongida and Dictyoceratida [2], and the sesquiterpene quinones spongiaquinone (3) and cyclospongiaquinone-1 (4), isolated from Stelospongia conulata [3,4] (Figure 1). On the other hand, the sesquiterpene quinines hydroquinones, zonarone (5), isozonarone (6), zonarol (7), isozonarol (8), yahazunol (9) and (-)-cyclozonarone (10) have been isolated from the brown alga Dictyopteris undulata [5] (Figure 1). Natural(-)-cyclozonarone (10) possesses powerful feeding-deterrent activity towards young abalones and furthermore it shows anti-cancer activity $[5,6]$. On the other hand, $(+)$-cyclozonarone shows antileshmanial activity and was recently shown to be cytotoxic toward different cancer cell lines $[7,8]$. The absolute configuration of $\mathbf{1 0}$ was established through a six-step synthesis route, starting from natural $(-)$ polygodial, leading us to the synthetic enantiomer $(+)$-cyclozonarone [9]. Later, $(-)$-cyclozonarone was synthesized starting from $(+)$-albicanol [10]. Both synthetic routes were based on the Diels-Alder reaction.

Figure 1. Some examples of natural sesquiterpenequinones.

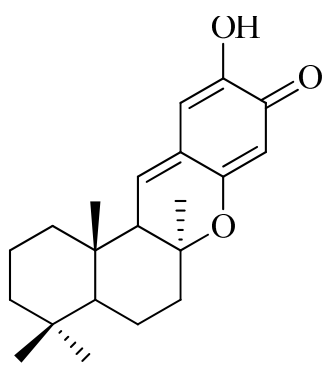

1

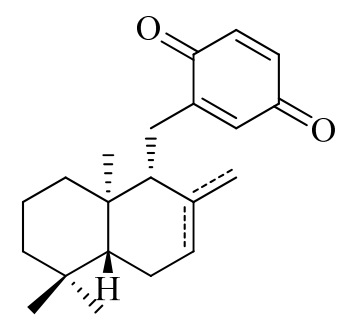

5 (exo)

6 (endo)

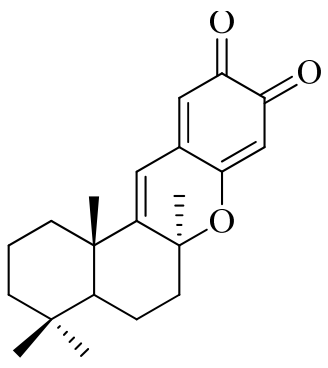

2

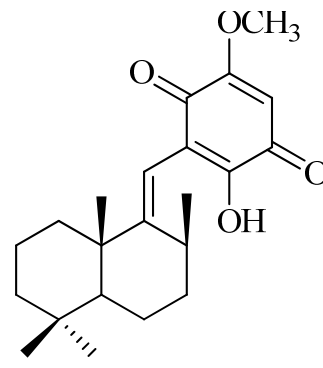

3

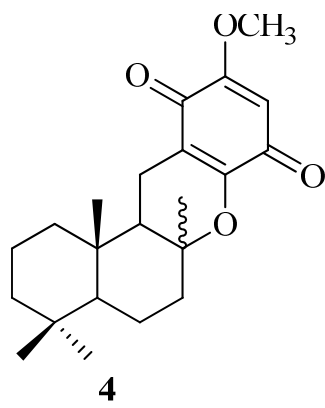

4

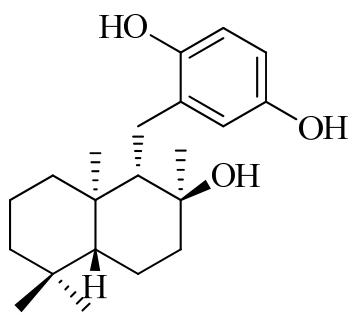

9

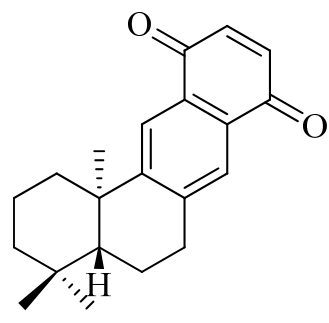

10

In the literaturequinone/hydroquinone cytotoxicity is usually attributed to two processes: redox cycling of quinones, resulting in the generation of reactive oxygen species which can damage biomolecules, and inhibition of mitochondrial function and electrophilic arylation of critical cellular nucleophiles. Both mechanisms can result in oxidative stress and cell death $[11,12]$.

Apoptosis or programmed cell death not only plays a crucial role in a range of pathological conditions, but is now recognized as an important component of multi-step carcinogenesis [13,14]. This physiological phenomenon represents terminal morphological and biochemical events and occurs through the activation of a cell-intrinsic suicide program [15]. This program is carried out following 
internal, as well as external signals, and is divided into various phases terminating with signals that initiate chromatin condensation, characterized by DNA fragmentation as well as by the loss of mitochondrial membrane integrity and release of molecules that initiate the activation of intracellular protease [14,16,17]. Mitochondria play a crucial role in the apoptotic cascade by serving as a center where apoptotic signals converge [18], given that changes induced in the mitochondrial membrane potential (MMP) have been reported previously to represent a determining step in the execution of cell death [19,20]. Reduction of the mitochondrial membrane potential causes the opening of the mitochondrial permeability transition pore, which leads to the release of apoptogenic factors and activation of caspases that are responsible for the morphological and biochemical events that characterize classical apoptosis [21,22].

Due to the interest of these meroterpenoids and other related compounds several synthetic strategies have been reported [23], and specifically we decided to synthesize an angular isomer 11 of (+)-cyclozonarone, easily prepared in a single step by a Diels-Alder reaction of 1,3 diene 12, prepared in turn from ketone 13, and 1,4-benzoquinone (Scheme 1).

Scheme 1. Retrosynthetic analysis to obtainof $(+)$-cyclozonarone.

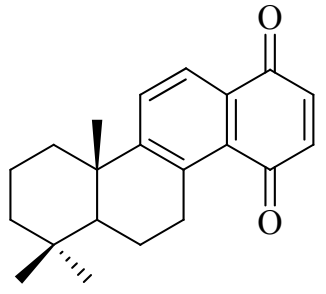

11

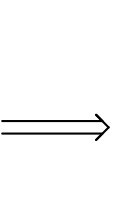<smiles>C=CC1=CCCC2C(C)(C)CCC[C@]12C</smiles>

12

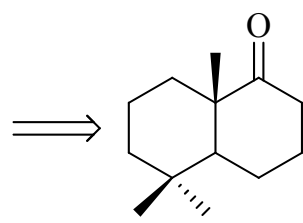

13

In addition, we have evaluated both sesquiterpene quinones $\mathbf{1 0}$ and $\mathbf{1 1}$ for theirinvitro cytotoxicity against cultured human colon and prostate cancer cells and human dermal fibroblasts (DHF). Moreover, in order to determine if they act as apoptosis inducers, we evaluated the condensation and fragmentation of chromatin determined by Hoechst staining, the activity of caspase 3 and the permeabilization of the mitochondrial membrane by rhodamine 123 staining and the activity of caspase $3[24,25]$.

\section{Results and Discussion}

\subsection{Chemistry}

When polygodial (14), obtained from the hexane extract of the bark of DrimyswinteriForst. [7], was treated with sodium borohydride in methanol at room temperature it produced diol $\mathbf{1 5}$ in excellent yield. It was previously reported that treatment of diol 15 with one equivalent of tert-butyl-diphenylsilyl chloride in DMF, in the presence of imidazole, produced silyl ether 16, with specificity towards the allylic alcohol, and excellent yield [26]. Unsaturated alcohol 16 was subjected to oxidation with Jones reagent affording enone $\mathbf{1 7}$ in moderate yield. Deprotection of silylether $\mathbf{1 7}$ with tetrabutylammonium fluoride in anhydrous tetrahydrofuran furnished alcohol 18 quantitatively. Catalytic hydrogenation of 18 afforded a mixture $\mathbf{1 9}$ of epimeric diols which, treated with Jones reagent, afforded the unsaturated ketone 13, that had been obtained previously from confertifoline [27,28]. 
Diene 12 was obtained by dehydration of allyl alcohol 20, prepared by addition of vinylmagnesium bromide to ketone 13. Finally, according to Scheme 2, diene 12 was condensed with 1,4-benzoquinone in benzene under thermal activation, and treated subsequently with DBU giving access to the aromatized product 11 in $33 \%$ yield.

Scheme 2. Synthesis of compound 11.

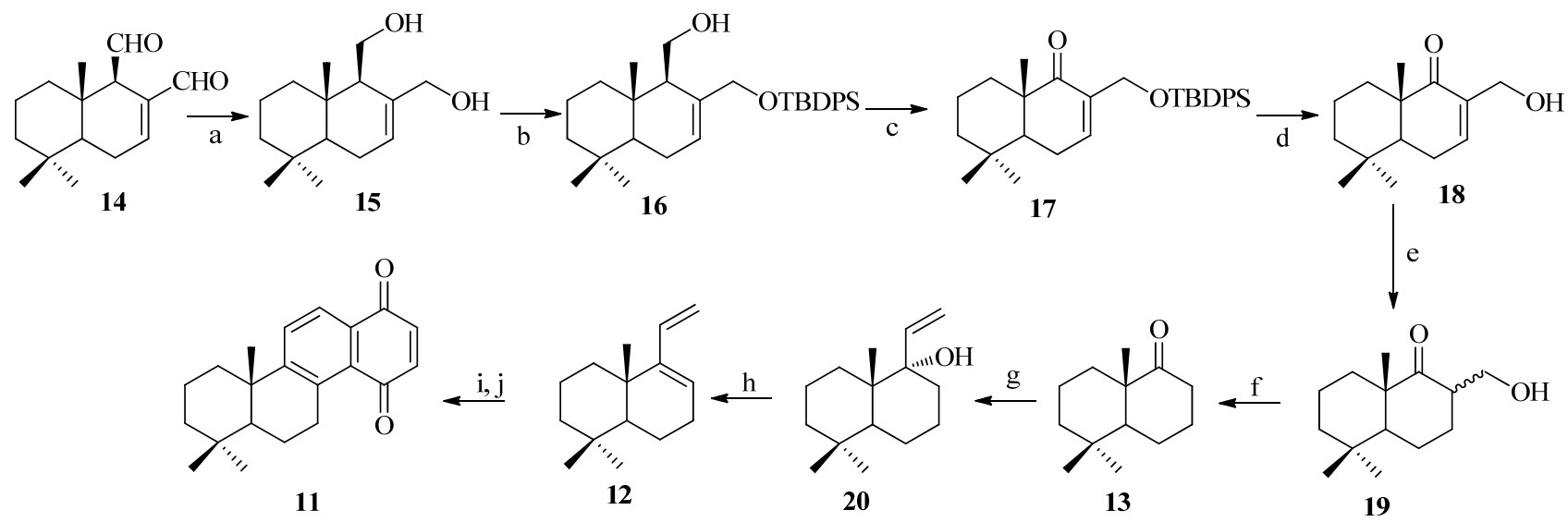

Reagents and Conditions: (a) $\mathrm{NaBH}_{4} / \mathrm{MeOH}, 90 \%$; (b) ClTBDPS, imidazole, DMF, 97\%; (c) Jones reagent, acetone, 49.4\%; (d) TBAF, THF,95\%; (e) $\mathrm{H}_{2}, \mathrm{PtO}_{2}, 79 \%$; (f) Jones reagent, acetone, 60\%; (g) vinylmagnesium bromide, THF, 27\%; (h) thionyl chloride, Py, 52.5\%; (i) $p$-benzoquinone, Bz, reflux, 12 h; (j) DBU, Bz, 2 h, 33\%.

The structural confirmation of new compound $\mathbf{1 1}$ was based on a careful analysis of its ${ }^{1} \mathrm{H}-$ and ${ }^{13} \mathrm{C}-\mathrm{NMR}$ spectra, with the help of a combination of $1 \mathrm{D}$ and $2 \mathrm{D}$ experiments, particularlyheteronuclear multiple-bond correlations (HMBC and HSQC).

In the ${ }^{1} \mathrm{H}-\mathrm{NMR}$ spectrum of $\mathbf{1 1}$, the signals at $\delta=7.98 \mathrm{ppm}(1 \mathrm{H}, \mathrm{d}, J=8.3 \mathrm{~Hz})$ and $\delta=7.72 \mathrm{ppm}(1 \mathrm{H}$, $\mathrm{d}, J=8.3 \mathrm{~Hz}$ ) were to assigned to the $\mathrm{H}-12$ and $\mathrm{H}-11$ hydrogens, respectively. The signal at $\delta=7.98$ ppm showed an HSQC ${ }^{1} J_{\mathrm{HC}}$ correlation with C-12 at $\delta_{\mathrm{C}}=124.9 \mathrm{ppm}$ and an $\mathrm{HMBC}{ }^{3} J_{\mathrm{HC}}$ correlation with carbonyl carbon $\mathrm{C}-1$ at $\delta_{\mathrm{C}}=185.6 \mathrm{ppm}$. Additionally, $\mathrm{H}-12$ showed HMBC correlations with the quaternary aromatic carbon $\mathrm{C}-10 \mathrm{~b}\left(\delta_{\mathrm{C}}=158.3 \mathrm{ppm} ;{ }^{3} J_{\mathrm{HC}}\right)$ and with $\mathrm{C}-11\left(\delta_{\mathrm{C}}=129.2 \mathrm{ppm} ;{ }^{2} J_{\mathrm{HC}}\right)$ (see Figure 2).

Figure 2. Major HMBC correlations observed for compound 11.
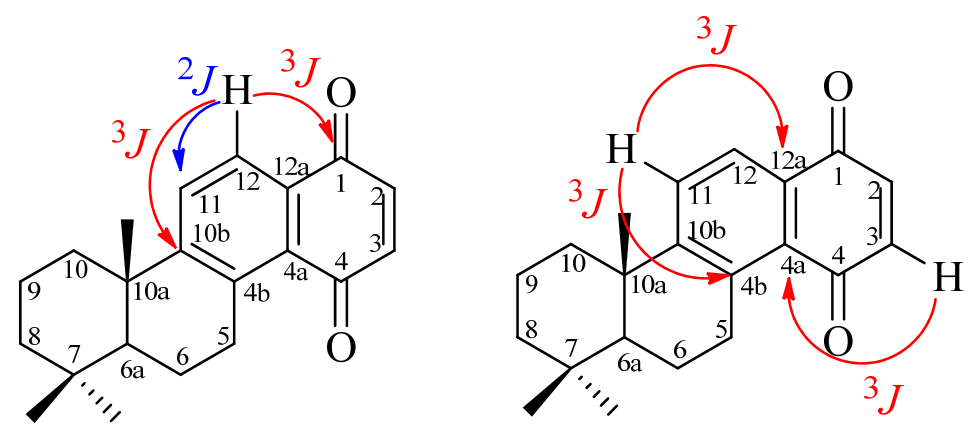

On the other hand, the signal at $\delta_{\mathrm{H}}=7.72 \mathrm{ppm}(\mathrm{H}-11)$ showed an HSQC correlation with $\mathrm{C}-11$ at $\delta_{\mathrm{C}}=124.9 \mathrm{ppm}\left({ }^{1} J_{\mathrm{HC}}\right)$ and $\mathrm{HMBC}$ correlations with $\mathrm{C}-12 \mathrm{a}\left(\delta_{\mathrm{C}}=131.3 \mathrm{ppm}\right)$ and $\mathrm{C}-4 \mathrm{~b}\left(\delta_{\mathrm{C}}=139.9 \mathrm{ppm}\right.$; 
$\left.{ }^{3} J_{\mathrm{HC}}\right)$. Finally, the carbonyl carbons C-1 $\left(\delta_{\mathrm{C}}=185.6 \mathrm{ppm}\right)$ and C-4 $\left(\delta_{\mathrm{C}}=187.7 \mathrm{ppm}\right)$ were unequivocally assigned when $\mathrm{H}-12$ showed an $\mathrm{HMBC}{ }^{3} J_{\mathrm{HC}}$ correlation with $\mathrm{C}-1$. Additionally, in the ${ }^{13} \mathrm{C}-\mathrm{NMR}$ spectrum the signal at $\delta_{\mathrm{C}}=130.2 \mathrm{ppm}$ was assigned to C-4a by observation of $\mathrm{HMBC}{ }^{3} J_{\mathrm{HC}}$ correlations with H-2 and/or H-3 at $\delta=6.87$ ppm (s, 2H) All these correlations are shown in Figure 2.

\subsection{Biology}

The cytotoxicity of the compounds was evaluated in vitro against different cancer cell lines: HT29 colon cancer, PC-3 and DU-145 human prostate cancer and one non-tumoral cell line, human dermal fibroblasts (DHF). A conventional colorimetric assay was set up to estimate the $\mathrm{IC}_{50}$ values, which represent the concentration of a drug that is required for $50 \%$ inhibition in vitro after $72 \mathrm{~h}$ of continuous exposure to the test compounds. Four serial dilutions (from 12.5 to $100 \mu \mathrm{M}$ ) for each sample were evaluated in triplicate. The results obtained from these assays are shown in Table 1. The highest cytotoxicity values were observed for ent-cyclozonarone[(+)-(10)] in all cell lines tested and were approximately twice more active than those of compound $\mathbf{1 1}$. The cytotoxicity of compounds $(+)-\mathbf{1 0}$ and 11 in fibroblasts is lower than in the cancer cell lines under study, indicating that the compounds are selectively toxic to cancer cells.

Table 1. Cytotoxicity $\left(\mathrm{IC}_{50} \mu \mathrm{M}\right)$ of (+)-10 and $\mathbf{1 1 .}$

\begin{tabular}{ccccc}
\hline Compound & DU-145 & PC-3 & HT-29 & DHF \\
\hline$(+)-\mathbf{1 0}$ & $6.4 \pm 0.8$ & $9.5 \pm 1.2$ & $25.0 \pm 0.9$ & $48.0 \pm 2.3$ \\
$\mathbf{1 1}$ & $13.3 \pm 1.4$ & $14.9 \pm 1.8$ & $45.0 \pm 0.5$ & $91.0 \pm 7.8$ \\
\hline
\end{tabular}

Since compounds $(+)-\mathbf{1 0}$ and $\mathbf{1 1}$ had strong inhibitory effects on the growth of the cancer cell types tested, we decided to study the effect of these compounds in greater detail. First, we analyzed the appearance of morphological changes in the cells treated with $25 \mu \mathrm{M}$ compound for $24 \mathrm{~h}$. Direct observation using a phase contrast microscope revealed that the morphology of PC-3 and HT-29 cells was severely distorted and cells became rounded, more clearly after treatment with $(+)-\mathbf{1 0}$. Moreover, the cells showed a reduction in number, indicating an increasing progression toward cell death. The control-treated cells displayed normal and healthy shapes (Figure 3).

To elucidate whether compounds (+)-10 and $\mathbf{1 1}$ reduced cell viability of HT29, PC-3, DU-145 and DHF cells by inducing apoptosis, cells treated with each compound were examined after Hoechst 33342 staining. The nuclear changes in HT29, PC-3, DU-145 and HDF cells were also observed under a fluorescence microscope $(200 \times)$. Exposure to compounds (+)-10 and $\mathbf{1 1}$ significantly affected the condensation and fragmentation of the nuclei in the treated cells (Figure 4). Following incubation with the compounds for $24 \mathrm{~h}$, the fluorescent emission was denser and brighter compared to control-treated cells. Also, the cells showed chromatin condensation and karyopyknosis, which are typical apoptotic phenomena. 
Figure 3. Effect of tested compounds on the morphology of HT-29 and PC-3 cells. Images obtained with an inverted phase contrast microscope $(200 \times)$ after $24 \mathrm{~h}$ exposure of the cells to $25 \mu \mathrm{M}(+)-\mathbf{1 0}$ or $\mathbf{1 1}$.

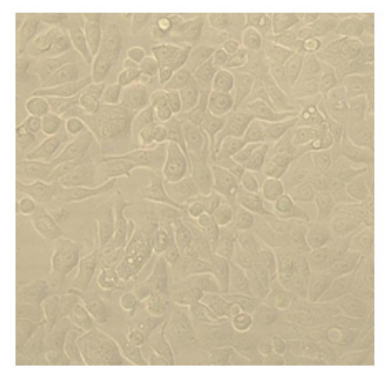

EtOH

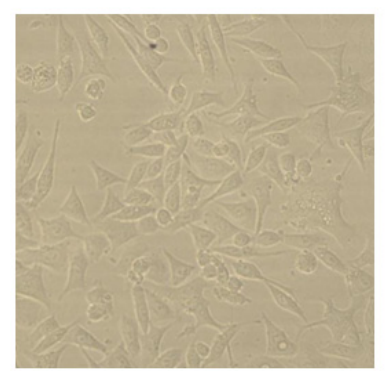

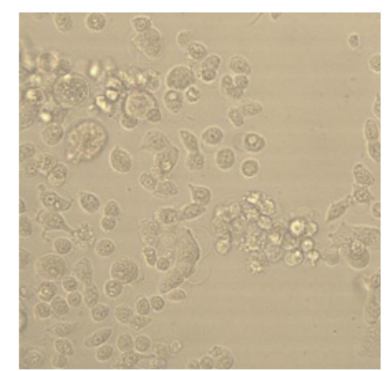

Compound 10

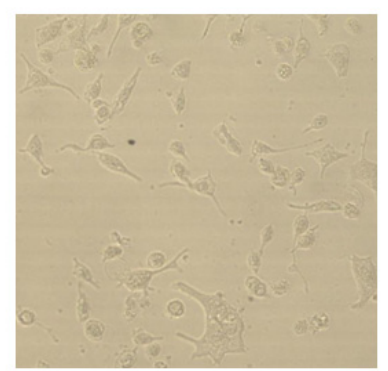

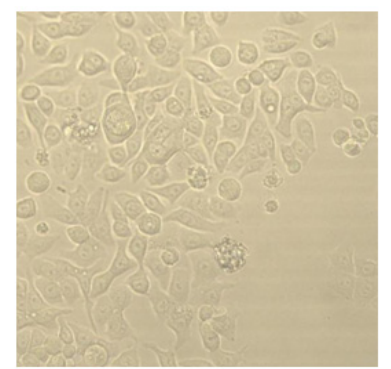

Compound 11

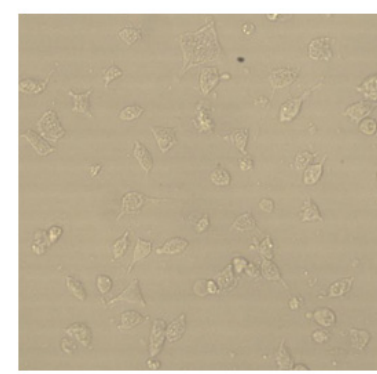

HT-29

PC-3

Figure 4. Effect of ent-cyclozonarone and compound 11 on chromatin condensation and fragmentation. PC-3, HT-29, DU-145 and DHF cells treated with either compound were stained with Ho33342 (400×). Representative photographs of nuclear morphologic changes observed by fluorescent microscopy of the treated cells.

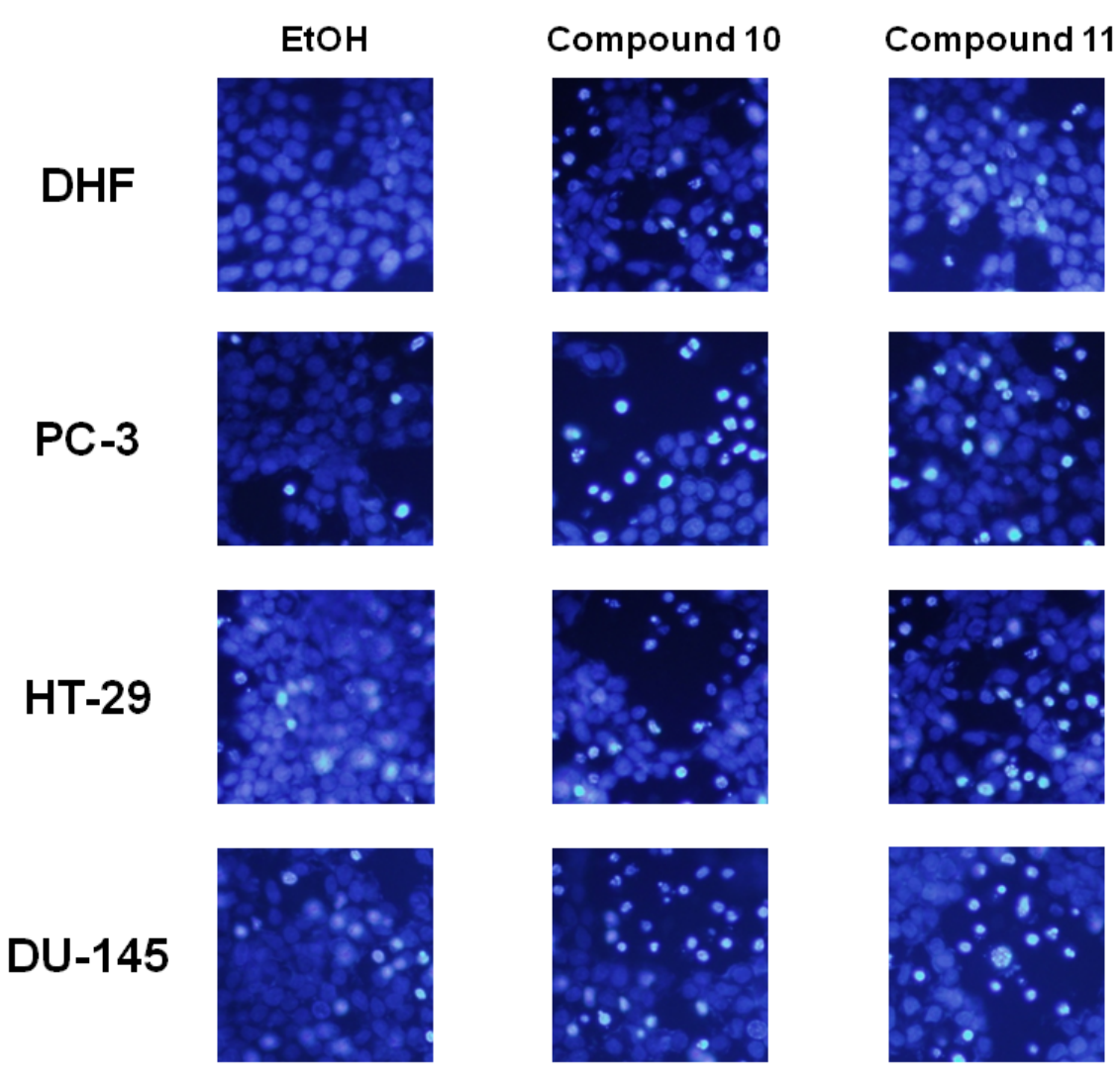


Changes induced in the mitochondrial membrane potential (MMP) have been reported previously to represent a determinant in the execution of cell death $[19,20]$. The effect of compounds $(+)-\mathbf{1 0}$ and 11 on the mitochondrial membrane potential was determined by flow cytometry using rhodamine 123 stain [29]. As shown in Figure 5, the percentage of rhodamine 123 stained-cells were $46.0 \pm 3.2 \%$, $3.5 \pm 1.1 \%, 0.5 \pm 1.0 \%$ and $38.5 \pm 3.5 \%$ in the DHF, HT-29, PC-3 and DU-145 cells, respectively, after treatment with $(+)-\mathbf{1 0}(25 \mu \mathrm{M})$; and $78.6 \pm 5.34 \%, 70.1 \pm 6.42 \%, 45.3 \pm 4.42 \%$ and $75.2 \pm 5.2 \%$, respectively, after treatment with 11, as compared to $80-85 \%$ in the control (ethanol-treated) cells. Figure 5 showed that compounds $(+)-\mathbf{1 0}$ and $\mathbf{1 1}$ induced increased mitochondrial membrane permeability in cancer cells with a greater effect of $(+)-\mathbf{1 0}$ in all cell lines tested. Moreover both compounds have a weaker effect on mitochondrial membrane potential in the fibroblast cell line, DHF. Thus, compounds $(+)-\mathbf{1 0}$ and $\mathbf{1 1}$ induced loss of mitochondrial membrane potential correlated with increased cell death (see Figure 5).

Figure 5. ent-Cyclozonarone $[(+)-10]$ and 11 treatment-induced changes in the mitochondrial membrane permeability in HDF, HT-29, PC-3 and DU-145 cells. The cells were stained with rhodamine 123, and then analyzed by flow cytometry. Representative histograms show changes in mitochondrial membrane permeability in DU-145, HT-29, PC-3 and DHF cells. The values indicate the percentages of the rhodamine 123 stained cells treated without or with the compounds $(+)-10$ or $11(25 \mu \mathrm{M}) .(* p<0.05$ or $* * p<0.001 v s$. control treated cells).

DHF

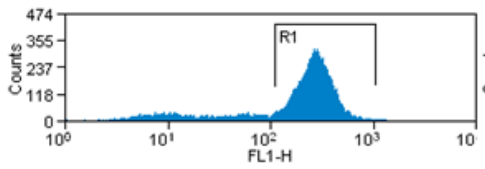

85.3

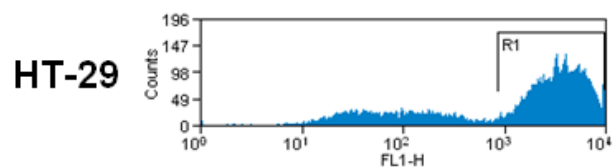

80.2
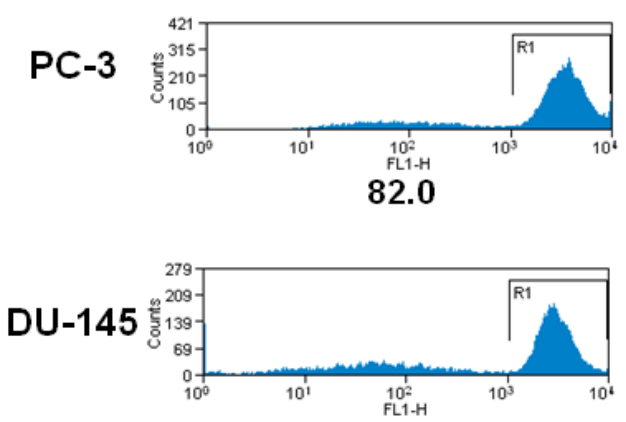

85.7

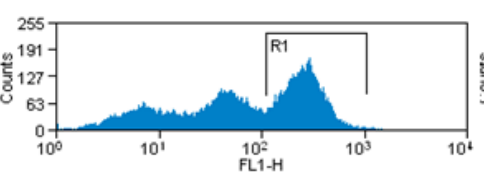

46.0

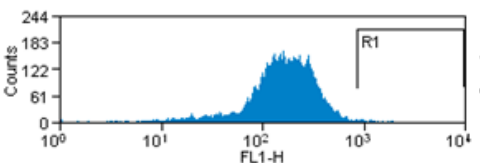

3.5

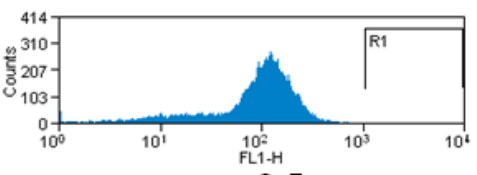

0.5

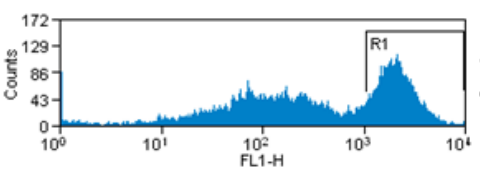

38.5

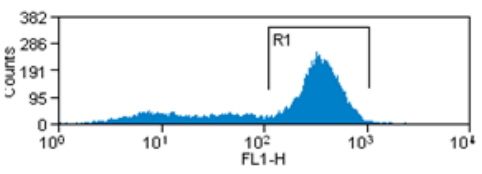

78.6

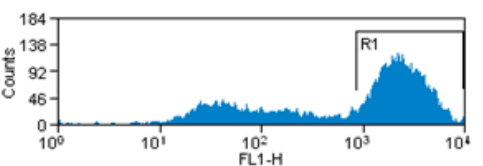

70.1

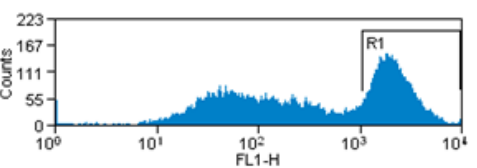

45.3

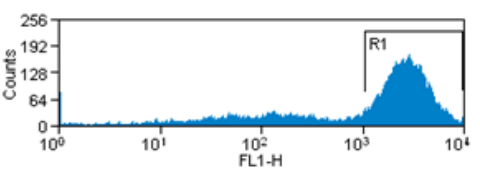

75.2

EtOH

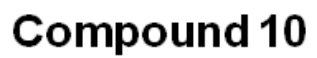

Compound 11

Then we investigated the effects of our compounds on caspase activity. We focused on caspase-3, which is activated by a great number of apoptotic signals. This enzyme is a main executor of apoptosis playing a central role in its biological processing. It has been reported that activation of caspase- 3 is an 
essential event for the induction of oligonucleosomal DNA fragmentation [30]. We analyzed the effect of treatment with the (+)-10 and $\mathbf{1 1}$ on caspase-3 activation in normal and cancer cells. As shown in Figure 6, the activation of caspase-3 in cells exposed to compounds $(+)-\mathbf{1 0}$ and $\mathbf{1 1}$ is increased versus control-treated cells. (+)-10 increased the activity of caspase 3 when compared with control by $3.6 \pm 0.3,3.0 \pm 0.1,4.0 \pm 0.3$, and 1.6 \pm 0.2 times in DU-145(black), PC-3 (white), HT29 (light gray) and DHF (dark gray) cells, respectively. Compound 11 increased the activity of caspase 3 by $3.4 \pm 0.2,2.8 \pm 0.3$, $3.8 \pm 0.4,1.5 \pm 0.2$ times versus control cells in DU-145, PC-3, HT29 and DHF cells, respectively).

Figure 6. Effect of ent-cyclozonarone and compound 11 on caspase-3 activity of DU-145 (black), PC-3 (white), HT-29 (light grey) and DHF (dark grey) cells. Cells were exposed to compounds at $25 \mu \mathrm{M}$ and incubated for $24 \mathrm{~h}$. Values are mean \pm S.D. $(n=3)$. All data are reported as the percentage change in comparison with the vehicle-treated cells, which were arbitrarily assigned $100 \% .{ }^{*} p<0.05$, significantly different from the vehicle-treated cells $(1 \%$ ethanol in medium, that is, compound concentration $=0) \# p<0.001$, significantly different from the vehicle-treated cells.

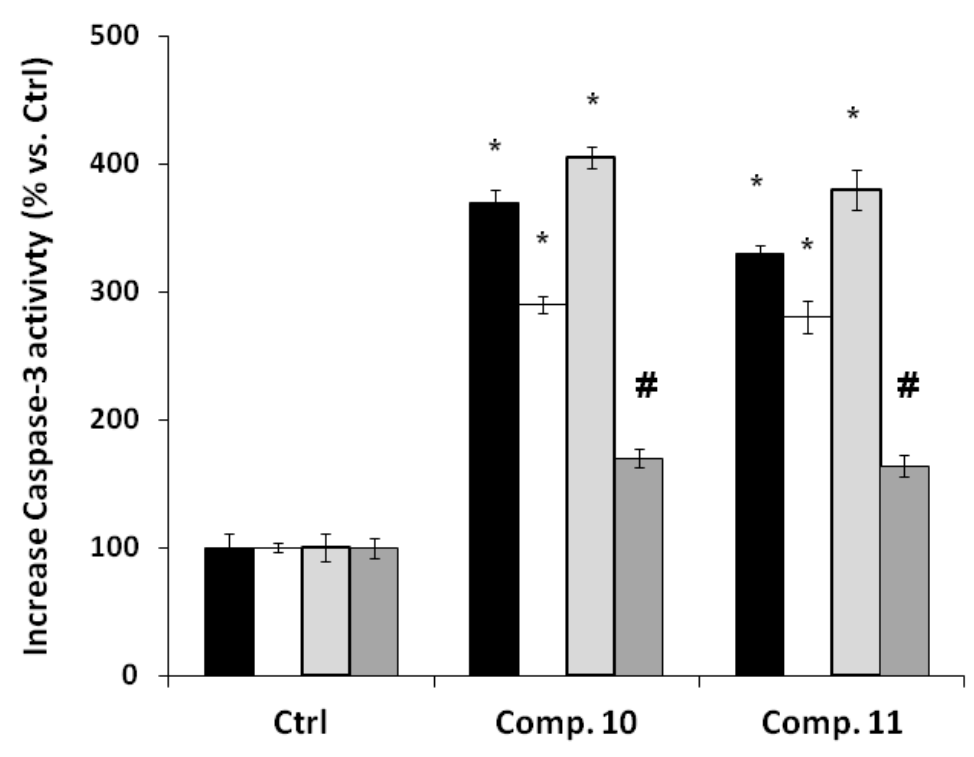

\section{Experimental}

\subsection{General}

Unless otherwise stated, all chemical reagents purchased (from Merck or Aldrich) were of the highest purity commercially available and were used without previous purification. Melting points were determined (in triplicate) on a Stuart-Scientific SMP3 apparatus and are uncorrected. Optical rotations were measured with a sodium lamp $(\lambda=589 \mathrm{~nm}$, D line $)$ on a Perkin Elmer 241 digital polarimeter equipped with $1 \mathrm{dm}$ cells at the temperature indicated in each case. Elemental analyses were obtained in a Fison Instruments EA 1108 microanalyzer. ${ }^{1} \mathrm{H}-,{ }^{13} \mathrm{C}$ - (DEPT 135 and DEPT 90), HSQC and HMBC spectra were recorded in $\mathrm{CDCl}_{3}$ solutions and are referenced to the residual peaks of $\mathrm{CHCl}_{3}$ at $\delta 7.26$ ppm and $\delta 77.0 \mathrm{ppm}$ for ${ }^{1} \mathrm{H}$ and ${ }^{13} \mathrm{C}$, respectively, on a Bruker Avance 400 Digital NMR spectrometer, operating at $400.1 \mathrm{MHz}$ for ${ }^{1} \mathrm{H}$ and $100.6 \mathrm{MHz}$ for ${ }^{13} \mathrm{C}$. Chemical shifts are reported in $\delta$ ppm and coupling constants $(J)$ are given in Hz. Silica gel (Merck 200-300 mesh) was used for column 
chromatography and silica gel plates HF-254 for TLC. TLC spots were detected by heating after spraying with $25 \% \mathrm{H}_{2} \mathrm{SO}_{4}$ in $\mathrm{H}_{2} \mathrm{O}$. Polygodial (14) was obtained by multigram preparative column chromatography (hexane: ethyl acetate gradient) from the crude hexane extract of the ground stem bark of Drimyswinteri Forst., as previously described [26]. Compounds 15-19 and $\mathbf{1 3}$ were synthesized using protocols reported in the literatura and the identities were established by comparison with the previously reported spectral data [26-28]. The syntheses of compounds $\mathbf{1 1}, \mathbf{1 2}$ and $\mathbf{2 0}$ are described below.

(1S,4aS,8aS)-5,5,8a-Trimethyl-1-vinyldecahydronaphthalen-1-ol (20). Ketone 13 (140 mg, $0.72 \mathrm{mmol})$ was dissolved in anhydrous THF $(10 \mathrm{~mL})$ and cooled to $-78{ }^{\circ} \mathrm{C}$. Vinylmagnesium bromide $(1 \mathrm{~mL}$, of a $1.0 \mathrm{M}$ solution, $1.0 \mathrm{mmol}$ ) was added dropwise. The mixture was allowed to warm to room temperature over $1 \mathrm{~h}$, and a saturated aqueous solution of $\mathrm{NH}_{4} \mathrm{Cl}$ was added. The resulting slurry was diluted with ethyl acetate $(100 \mathrm{~mL})$ and washed with water $(50 \mathrm{~mL})$. The organic phase was dried $\left(\mathrm{MgSO}_{4}\right)$ and concentrated. After a column chromatographic purification using a mixture of hexane and ethyl-acetate with increasing polarity (49:1 and 1:49) alcohol 20 (70 mg, 27\%) was obtained as a colourless oil. ${ }^{1} \mathrm{H}-\mathrm{NMR}\left(\mathrm{CDCl}_{3}\right) \delta: 6.03\left(1 \mathrm{H}, \mathrm{dd}, J_{\text {trans }}=17.3 \mathrm{~Hz} ; J_{\text {cis }}=10.9 \mathrm{~Hz}\right.$, vinyl proton $), 5.18(1 \mathrm{H}$, dd, $J_{\text {cis }}=10.9 \mathrm{~Hz} ; J_{\text {gem }}=0.7 \mathrm{~Hz}$, vinyl proton $), 5.09\left(1 \mathrm{H}, \mathrm{dd}, J_{\text {trans }}=17.3 \mathrm{~Hz} ; J_{\text {gem }}=0.7 \mathrm{~Hz}\right.$, vinyl proton), 0.97 (3H, s, 8- $\alpha-\mathrm{Me}), 0.89$ (3H, s, 5- $\alpha-\mathrm{Me}), 0.84(3 \mathrm{H}, \mathrm{s}, 5-\beta-\mathrm{Me}) .{ }^{13} \mathrm{C}-\mathrm{NMR}\left(\mathrm{CDCl}_{3}\right) \delta: 142.8(=\mathrm{CH})$, $113.3\left(=\mathrm{CH}_{2}\right), 53.5$ (C-1), 45.7 (C-4a), 41.9 (C-6), $41.1(\mathrm{C}-8 \mathrm{a}), 33.7$ (5- $\left.\alpha-\mathrm{Me}\right), 33.4(\mathrm{C}-2), 33.2(\mathrm{C}-5)$, 32.1 (C-8), 21.9 (5- $\beta-\mathrm{Me}), 21.9$ (C-3), 21.4 (C-4), 18.5 ( C-7), 16.9 (8a-Me), in accordance with literature [28].

(4oS, $8 \alpha S)-4,4,8 \alpha$-Trimethyl-8-vinyl-1,2,3,4,4a,5,6,8a-octahydronaphthalene (12). Thionyl chloride $(0.10 \mathrm{~mL}, 1.16 \mathrm{mmol})$ was added dropwise at $-30{ }^{\circ} \mathrm{C}$ to a solution of enol20 $(70 \mathrm{mg}, 0.31 \mathrm{mmol})$ in anhydrous pyridine $(4 \mathrm{~mL})$. The solution was brought to $0{ }^{\circ} \mathrm{C}$ and stirred for $1 \mathrm{~h}$. The reaction mixture was diluted with hexane and washed with dilute $\mathrm{HCl}$ and then with saturated $\mathrm{NaHCO}_{3}$. The organic phase was dried and concentrated. Purification by column chromatography using a mixture of hexane and ethyl-acetate with increasing polarity (49:1 and 1:49) afforded diene $\mathbf{1 2}(40 \mathrm{mg}, 52.5 \%)$ as a colorless oil. ${ }^{1} \mathrm{H}-\mathrm{NMR}\left(\mathrm{CDCl}_{3}\right) \delta: 6.31\left(1 \mathrm{H}, \mathrm{dd}, J_{\text {cis }}=10.7 \mathrm{~Hz}, J_{\text {trans }} 17.0 \mathrm{~Hz},=\mathrm{CH}\right), 5.63(1 \mathrm{H}, \mathrm{t}$, $J=3.9 \mathrm{~Hz}, \mathrm{H}-7), 5.23\left(1 \mathrm{H}, \mathrm{dd}, J_{\text {gem }}=2.2 \mathrm{~Hz}, J_{\text {trans }} 17.0 \mathrm{~Hz},=\mathrm{CH}_{2}\right), 4.89\left(1 \mathrm{H}, \mathrm{dd}, J_{\text {gem }}=2.2 \mathrm{~Hz}, J_{\text {cis }}=10.7\right.$ $\left.\mathrm{Hz},=\mathrm{CH}_{2}\right), 2.12-0.95(11 \mathrm{H}, \mathrm{m}), 1.06(3 \mathrm{H}, \mathrm{s}, 8-\alpha-\mathrm{Me}), 0.90(3 \mathrm{H}, \mathrm{s}, 4-\alpha-\mathrm{Me}), 0.85$ (3H, s, 4- $\left.\beta-\mathrm{Me}\right)$,in accordance with literature[28].

(6aS,10aS)-7,7,10a-Trimethyl-5,6,6a,7,8,9,10,10a-octahydrochrysene-1,4-dione (11). A mixture of diene $12(40 \mathrm{mg}, 0.20 \mathrm{mmol})$ and $p$-benzoquinone $(32 \mathrm{mg}, 0.30 \mathrm{mmol})$ in benzene $(2 \mathrm{~mL})$ was stirred at refluxfor $12 \mathrm{~h}$, after which TLC analysis showed the disappearance of the starting material. The solution was allowed to cool to room temperature, and DBU (2 drops) was added with stirring. The reaction mixture was concentrated (rotary evaporator), and the residue purified by column chromatography using a mixture of hexane and ethyl-acetate with increasing polarity (49:1 and 1:49) to yield quinine $\mathbf{1 1}(5.2 \mathrm{mg}$, $33.0 \%)$ as yellow crystals, m.p. $106-108{ }^{\circ} \mathrm{C} .[\alpha]_{D}^{20}=1,05^{\circ}\left(\mathrm{c}=0.3 \mathrm{CHCl}_{3}\right)$. Analysis: calculated for $\mathrm{C}_{21} \mathrm{H}_{24} \mathrm{O}_{2}, \mathrm{C}=81.78 \%, \mathrm{H}=7.84 \%$, found: $\mathrm{C}=81.52 \%, \mathrm{H}=7.77 \%$. The assignment of the signals in the ${ }^{1} \mathrm{H}-\mathrm{NMR}\left(\mathrm{CDCl}_{3}\right)$ and ${ }^{13} \mathrm{C}-\mathrm{NMR}\left(\mathrm{CDCl}_{3}\right)$ spectra are shown in the Table 2. 
Table 2. ${ }^{1} \mathrm{H}-\mathrm{NMRchemical}$ shifts, $\delta$ (ppm), coupling constants $\mathrm{J}(\mathrm{H}, \mathrm{H})(\mathrm{Hz})$, and ${ }^{13} \mathrm{C}-\mathrm{NMR}$ chemical shifts, $\delta$ (ppm), for compound 11.

\begin{tabular}{|c|c|c|}
\hline Position & ${ }^{1}$ H-NMR & ${ }^{13} \mathrm{C}-\mathrm{NMR}$ \\
\hline 1 & - & 185.6 \\
\hline 2 & $6.87(1 \mathrm{H}, \mathrm{s})$ & $141.1 *$ \\
\hline 3 & $6.87(1 \mathrm{H}, \mathrm{s})$ & $136.2 *$ \\
\hline 4 & - & 187.7 \\
\hline $4 \mathrm{a}$ & - & 129.2 \\
\hline $4 \mathrm{~b}$ & - & 139.9 \\
\hline 5 & $3.52(1 \mathrm{H}, \mathrm{ddd}, 6.0,6.0,19.7) ; 3.29(1 \mathrm{H}, \mathrm{ddd}, 8.1,11.2,19.7)$ & 30.2 \\
\hline 6 & $1.69(2 \mathrm{H}, \mathrm{m})$ & 19.3 \\
\hline $6 a$ & $1.34(1 \mathrm{H}, \mathrm{dd}, 2.01,12.4)$ & 49.0 \\
\hline 7 & - & 29.7 \\
\hline 8 & $1.53(1 \mathrm{H}, \mathrm{bs}, 13.2) ; 1.3(1 \mathrm{H}, \mathrm{m})$ & 41.2 \\
\hline 9 & $2.02(1 \mathrm{H}, \mathrm{m}) ; 1.65(1 \mathrm{H}, \mathrm{m})$ & 18.8 \\
\hline 10 & $2.34(1 \mathrm{H}, \mathrm{bs}, 12.7) ; 1.41(1 \mathrm{H}, \mathrm{dd}, 3.7,12.9)$ & 39.2 \\
\hline $10 \mathrm{a}$ & - & 33.4 \\
\hline $10 \mathrm{~b}$ & - & 158.3 \\
\hline 11 & $7.72(1 \mathrm{H}, \mathrm{d}, 8.3)$ & 130.2 \\
\hline 12 & $7.98(1 \mathrm{H}, \mathrm{d}, 8.3)$ & 124.9 \\
\hline $12 \mathrm{a}$ & - & 131.3 \\
\hline $7-\alpha-\mathrm{Me}$ & $1.00(3 \mathrm{H}, \mathrm{s})$ & 33.1 \\
\hline 7- $\beta-\mathrm{Me}$ & $0.97(3 \mathrm{H}, \mathrm{s})$ & 24.7 \\
\hline $10 \mathrm{a}-\mathrm{Me}$ & $1.27(3 \mathrm{H}, \mathrm{s})$ & 21.6 \\
\hline
\end{tabular}

\subsection{Cell Lines}

The experimental cell cultures were obtained from the American Type Culture Collection (Rockville, MD, USA). HT-29 cells (colon cancer cell line), PC-3 and DU-145 (prostate cancer cell lines) and human dermal fibroblasts (DHF) were grown in Dulbecco's modified Eagle's medium (DMEM) containing $10 \% \mathrm{FCS}, 100 \mathrm{U} / \mathrm{mL}$ penicillin, $100 \mu \mathrm{g} / \mathrm{mL}$ streptomycin and $1 \mathrm{mM}$ glutamine. Cells were seeded into 96 well microtiter plates in $100 \mu \mathrm{L}$ at a plating density of $5 \times 10^{3}$ cells/well. After $24 \mathrm{~h}$ incubation at $37{ }^{\circ} \mathrm{C}$ under a humidified $5 \% \mathrm{CO}_{2}$ atmosphere to allow cell attachment, the cells were treated with different concentrations of drugs and incubated for $72 \mathrm{~h}$ under the same conditions. Stock solutions of compounds were prepared in ethanol and the final concentration of this solvent was kept constant at $1 \%$. Control cultures received $1 \%$ ethanol alone.

\subsection{Cell Viability}

\subsubsection{In Vitro Growth Inhibition Assay}

The sulforhodamine B assay was used according to the method of Skehanet al. [29]. Briefly, the cells were set up at $3 \times 10^{3}$ cells per well of a 96-flat-bottomed, $200 \mu \mathrm{L}$ well microplate. Cells were incubated at $37{ }^{\circ} \mathrm{C}$ in a humidified $5 \% \mathrm{CO}_{2} / 95 \%$ air mixture and treated with the compounds at different 
concentrations for $72 \mathrm{~h}$. At the end of drug exposure, cells were fixed with 50\% trichloroacetic acid at $4{ }^{\circ} \mathrm{C}$. After washing with water, cells were stained with $0.1 \%$ sulforhodamine B (Sigma-Aldrich, St. Louis, MO, USA), dissolved in $1 \%$ acetic acid (50 $\mu \mathrm{L} /$ well) for $30 \mathrm{~min}$, and subsequently washed with $1 \%$ acetic acid to remove unbound stain. Protein-bound stain was solubilized with $100 \mu \mathrm{L}$ of $10 \mathrm{mM}$ unbuffered Tris base, and the cell density was determined using a fluorescence plate reader (wavelength $540 \mathrm{~nm}$ ). Values shown are the mean \pm SD of three independent experiments in triplicate. The software used to calculate the $\mathrm{IC}_{50}$ values was GraphPad (GraphPad Software, San Diego, CA, USA).

\subsection{Morphological Assessment of Cell Apoptosis}

Hoechst 33342

Morphological changes in the nuclear chromatin of cells undergoing apoptosis were revealed by a nuclear fluorescent dye, Hoechst 33342. Briefly, on 24-well chamber slides, $1 \times 10^{4}$ cells $/ \mathrm{mL}$ DHF, HT-29, PC-3 and DU-145 were cultured and exposed to compounds for $24 \mathrm{~h}$. The control group was also exposed to $1 \%$ ethanol. The cells were washed twice with phosphate buffer solution, fixed with $3.7 \%$ formaldehyde and washed again with phosphate buffer solution. Following the addition of $1 \mu \mathrm{M}$ Hoechst 33342 (Sigma-Aldrich, Santiago, Chile), they were reacted in a dark room at room temperature for $30 \mathrm{~min}$. After washing, they were examined under an immunofluorescence microscope (Olympus IX 81 model inverted microscope).

\subsection{Analysis of Mitochondrial Membrane Permeability}

Rhodamine 123 , a cationic voltage-sensitive probe that reversibly accumulates in mitochondria, was used to detect changes in transmembrane mitochondrial membrane potential. Exponentially growing cells were incubated with the compound as indicated in the figure legends. Cells were labelled with $1 \mu \mathrm{M}$ rhodamine 123 at $37^{\circ} \mathrm{C}$ in cell medium for $60 \mathrm{~min}$ before terminating the experiment. Cells were detached from the plate, after washing with ice cold PBS, and the samples were analyzed by flow cytometry. Data are expressed in percentage of cells withrhodamine 123 [29].

\subsection{Caspase 3 Activity Assay}

Caspase activity was measured using a colorimetric assay. Briefly, the cells exposed to compounds were collected by centrifugation at $1000 \mathrm{rpm}$ and the cells were lysed with lysis buffer (1\% Triton $\mathrm{X}-100,0.32 \mathrm{M}$ sucrose, $5 \mathrm{mM}$ EDTA, $10 \mathrm{mM}$ Tris- $\mathrm{HCl}, \mathrm{pH} 8.0,2 \mathrm{mM}$ dithiothreitol, 1mM PMSF, $1 \mathrm{~g} / \mathrm{mL}$ aprotinin, $1 \mathrm{mg} / \mathrm{mL}$ leupeptin). Thereafter, the lysates were transferred to wells in a 96-well microplate and were incubated with DEVD-pNA (final concentration $200 \mu \mathrm{M}$ ) specific for caspase-3, at $37{ }^{\circ} \mathrm{C}$ for $1 \mathrm{~h}$. The intensity of the developed colour was read at $405 \mathrm{~nm}$ in a microplate reader (SpectraMax, Winooski, VT, USA). The results are expressed as percentages of the control level. 


\section{Conclusions}

In summary, we describe here the synthesis of a new ent-cyclozonarone angular isomer 11 andcompare its cytotoxicity and that of ent-cyclozonarone $[(+)-\mathbf{1 0}]$ toward normal and cancer human cells. The analyzed compounds induce cell death in different cancer cell lines by inducing dissipation of the mitochondrial membrane potential and the sequential activation of caspase-3 leading to apoptosis, the effects of $(+)-\mathbf{1 0}$ being stronger than those of 11. These compounds displayed promising activity and could be used as leads in the design and development of new anticancer drugs. However, additional studies to determine its in vivo biological activities and to identify the anti-tumor potential of these compounds, which may represent a promising candidate for in vivo studies of anti-tumor therapies, will be needed.

\section{Acknowledgements}

The authors thank the DGIP of Universidad Técnica Federico Santa María (PICC 2012) for financial support.

\section{Conflict of Interest}

The authors declare no conflict of interest.

\section{References}

1. Gordaliza, M. Cytotoxic terpene quinones from marine sponges. Mar. Drugs 2010, 8, 2849-2870.

2. Hamann, M.T.; Scheuer, P.J.; Kellyborges, M. Biogenetically diverse, bioactive constituents of a sponge, order verongida-bromotyramines and sesquiterpene-shikimate derived metabolites. J. Org. Chem.1993, 58, 6565-6569.

3. Capon, R.J.; Groves, D.R.; Urban, S.; Watson, R.G. Spongiaquinone revisited-Structural and stereochemical studies on marine sesquiterpene quinones from a southern australian marine sponge,spongia sp. Aust. J. Chem. 1993, 46, 1245-1253.

4. Kazlauskas, R.; Murphy, P.; Warren, R.; Wells, R.; Blount, J. New quinones from a dictyoceratid sponge. Aust. J. Chem. 1978, 31, 2685-2697.

5. Kurata, K.; Taniguchi, K.; Suzuki, M. Cyclozonarone, a sesquiterpene-substituted benzoquinone derivative from the brown alga Dictyopteris undulata. Phytochemistry 1996, 41, 749-752.

6. Laube, T.; Beil, W.; Seifert, K. Total synthesis of two 12-nordrimanes and the pharmacological active sesquiterpene hydroquinone yahazunol. Tetrahedron 2005, 61, 1141-1148.

7. Cuellar, M.A.; Salas, C.; Cortes, M.J.; Morello, A.; Maya, J.D.; Preite, M.D. Synthesis and in vitro trypanocide activity of several polycyclic drimane-quinone derivatives. Bioorg. Med. Chem. 2003, 11, 2489-2497.

8. Delgado, V.; Armstrong, V.; Cortes, M.; Barrero, A.F. Synthesis of racemic and chiral albicanol, albicanyl acetate and cyclozonarone: Cytotoxic activity of ent-cyclozonarone. J. Braz. Chem. Soc. 2008, 19, 1258-1263. 
9. Cortes, M.; Valderrama, J.A.; Cuellar, M.; Armstrong, V.; Preite, M. Synthesis of $(+)$-cyclozonarone and the absolute configuration of naturally occurring (-)-cyclozonarone. J. Nat. Prod. 2001, 64, 348-349.

10. Schroder, J.; Matthes, B.; Seifert, K. Total synthesis of the marine sesquiterpene quinone (-)-cyclozonarone. Tetrahedron Lett. 2001, 42, 8151-8152.

11. Henry, T.R.; Wallace, K.B. Differential mechanisms of cell killing by redox cycling and arylating quinones. Arch. Toxicol.1996, 70, 482-489.

12. O'Brien, P.J. Molecular mechanisms of quinone cytotoxicity. Chem. Biol. Interac. 1991, 80, 1-41.

13. Reddy, L.; Odhav, B.; Bhoola, K.D. Natural products for cancer prevention: A global perspective. Pharmacol. Ther. 2003, 99, 1-13.

14. Ghobrial, I.M.; Witzig, T.E.; Adjei, A.A. Targeting apoptosis pathways in cancer therapy. CA Cancer J. Clin. 2005, 55, 178-194.

15. Wyllie, A.H. Apoptosis: An overview. Br. Med. Bull. 1997, 53, 451-465.

16. Makin, G.; Hickman, J.A. Apoptosis and cancer chemotherapy. Cell Tissue Res. 2000, 301, 143-152.

17. Fleischer, A.; Ghadiri, A.; Dessauge, F.; Duhamel, M.; Rebollo, M.P.; Alvarez-Franco, F.; Rebollo, A. Modulating apoptosis as a target for effective therapy. Mol. Immunol. 2006, 43,

18. Ka65-R079mi, M.; Tanabe, K. Role of mitochondria as the gardens of cell death. Cancer Chem. Pharmacol. 2006, 57, 545-553.

19. Guimaraes, C.A.; Linden, R. Programmed cell deaths-Apoptosis and alternative deathstyles. Eur. J. Biochem. 2004, 271, 1638-1650.

20. Lemasters, J.J.; Nieminen, A.L.; Qian, T.; Trost, L.C.; Elmore, S.P.; Nishimura, Y.; Crowe, R.A.; Cascio, W.E.; Bradham, C.A.; Brenner, D.A.; et al. The mitochondrial permeability transition in cell death: A common mechanism in necrosis, apoptosis and autophagy. Biochim. Biophys. Acta 1998, 1366, 177-196.

21. Reed, J.C.; Tomaselli, K.J. Drug discovery opportunities from apoptosis research. Curr. Opin. Biotech. 2000, 11, 586-592.

22. Mattson, M.P.; Kroemer, G. Mitochondria in cell death: Novel targets for neuroprotection and cardioprotection. Trends Mol. Med. 2003, 9, 196-205.

23. Gordaliza, M. Synthetic strategies to terpene quinones/hydroquinones. Mar. Drugs 2012, 10, $358-402$.

24. Li, W.; Lam, M.S.; Birkeland, A.; Riffel, A.; Montana, L.; Sullivan, M.E.; Post, J.M. Cell-based assays for profiling activity and safety properties of cancer drugs. J. Pharmacol. Toxicol. Methods 2006, 54, 313-319.

25. Kamb, A.; Lassota, P. Disease models of cancer: Apoptosis. Drug Discov. Today 2004, 1, 31-36.

26. Cuellar, M.A.; Moreno, L.E.; Preite, M.D. Regioselective oxidative fragmentation of drimanic terpene alcohols: A short, easy and efficient access to natural and synthetic 11-nordrimane terpene derivatives. ARKIVOC 2003, 169-177.

27. Benites, J.; Preite, M.D.; Cortes, M. Conversion of (+)-confertifolin into 11,12-bisnordriman-9-one and (+)-8 $\alpha \mathrm{H}, 9 \alpha \mathrm{H}-11,12$-diacetoxydrimane. Syn. Commun. 2001, 31, 1347-1354. 
28. Coisne, J.M.; Pecher, J. A terpene synthesis intermediate: $( \pm$ )-5-ethenyl-1, 1, 4a $\beta$-trimethyl-1, 2, 3, 4, 4a, 7, 8, 8a $\alpha$-octahydronaphthalene. Bull. Soc. Chim. Belg. 1980, 89, 551-557.

29. Emaus, R.K.; Grunwald, R.; Lemasters, J.J. Rhodamine 123 as a probe of transmembrane potential in isolated rat-liver mitochondria: Spectral and metabolic properties. Biochim. Biophys. Acta 1986, 850, 436-448.

30. Day, T.W.; Wu, C.H.; Safa, A.R. Etoposide induces protein kinase C $\delta$ - and caspase-3-dependent apoptosis in neuroblastoma cancer cells. Mol. Pharmacol. 2009, 76, 632-640.

Sample Availability: Not available.

(C) 2013 by the authors; licensee MDPI, Basel, Switzerland. This article is an open access article distributed under the terms and conditions of the Creative Commons Attribution license (http://creativecommons.org/licenses/by/3.0/). 